\title{
Columbian Cartel Launches Bid for
}

\section{Japanese Firms}

\author{
J. Mark Ramseyer ${ }^{\dagger}$
}

\section{INTRODUCTION}

Or so one would argue. With one of the brightest and most productive corps of corporate law scholars in the country, the Columbian cartel dominates much of the debate over American "corporate governance." Now Mark Roe-among the brightest and most productive in the cartel-extends that analysis to governance patterns in Japan (and Germany). The Japanese (and German) practice may even, he suggests tentatively, solve some of the problems the cartel finds in American governance.'

In tying Japan to this debate over "corporate governance," Roe does a brilliant job. Along the way, he raises two loosely related questions: whether the concept of "corporate governance" adequately explains the shareholding practices of Japanese banks and, more broadly, why the concept has become so prominent in recent corporate law scholarship. To explore these issues, I first review Roe's argument (Part I). I then demonstrate why "corporate governance" may not explain the Japanese phenomena he describes (Part I). In the process, I suggest that Japanese banks buy stock in their clients to exploit the inside information they acquire in the course of researching potential borrowers. I reach this conclusion by elimination; none of the explanations that either Roe or anyone else has advanced fits the facts observed. I conclude by asking why so many corporate law academics seem so obsessed with "corporate governance" (Part III). For many academics (including some Columbians but notably excluding Roe), the answer lies in a desire to promote mandatory terms-terms of the corporate contract that

$\dagger$ Professor of Law, University of Chicago. I gratefully acknowledge the financial assistance of the Lynde and Harry Bradley Foundation and the John M. Olin Foundation, money "I shall not be able to keep if I write many more articles [with titles] in this vein." Frank H. Easterbrook, The Most Insignificant Justice: Further Evidence, 50 U. CHIC. L. REV. 481, 481 n. $\dagger$ (1983). I received helpful comments and suggestions from a variety of friends, including Douglas Baird, Frank Easterbrook, Richard Epstein, Daniel Fischel, William Klein, Geoffrey Miller, Yoshiro Miwa, Frank Packer, Mark Roe, Frances Rosenbluth, Marc Ryser, and David Weinstein.

1. Mark J. Roe, Some Differences in Corporate Structure in Germany, Japan, and the United States, 102 YALE L.J. 1927 (1993). In this Comment, I address only Roe's comments on Japan and leave to others his views of German firms. 
investors and managers cannot agree to circumvent. ${ }^{2}$ By focusing attention on the notion that something is radically "wrong" with American corporate governance, these scholars seem to justify their attempts to dictate these terms. However much they cite Japan to buttress their proposals, though, Roe nicely shows why the Japanese example does not justify mandatory terms.

\section{LEGAL INFLUENCE}

Roe argues that many of the differences in the ways Japanese and Americans organize their firms result from regulatory differences. ${ }^{3}$ In this, he is surely right. Absent regulatory differences, competing capitalist firms will often resemble one another. Significant differences will sometimes remain, to be sure. We have only begun to learn how different any two firms can be, yet both stay competitive. Nonetheless, we should not miss the basic commonalities. Given similar product markets (most men in most developed countries crave Lethal Weapon videos), competing firms will tend to sell similar products. Given similar worker preferences (most workers everywhere want more money and shorter hours), competing firms will tend to adopt similar manufacturing practices. Given porous capital markets (most sophisticated investors can arbitrage international differences), competing firms should develop similar capital structures. And given similar investor preferences (all investors prefer more money to less), many firms that did anything else would eventually go broke.

In stressing the importance of regulatory differences, Roe shows the flair for sophisticated analysis that he has demonstrated in a variety of other contexts. He first contrasts the capital markets in the two countries: Japanese banks dominate domestic financial markets; American banks do not. He then explains the regulatory origins of this result. First, American banks face a variety of geographical and other legal restraints that Japanese banks escape. Second, American banks face fierce competition from other capital sources. Although Japanese banks face competitors too, Japanese regulators crippled the

2. On mandatory terms generally, see FranK H. EASTERBROOK \& DANIEL R. FISCHEL, THE ECONOMIC STruCTURE OF CORPORATE LAW (1991). Among the more sophisticated and thoughtful proposals are requirements that shareholders nominate a large fraction of a firm's directors, e.g., LOUIS LOWENSTEIN, What's Wrong WITH WALl STREET: ShorT TERM GAIN AND THE ABSENTEe ShaReholder (1988), rules that give shareholders a louder voice in annual meetings, e.g., Bernard S. Black, Agents Watching Agents: The Promise of Institutional Investor Voice, 39 UCLA L. REV. 811 (1992), and regulations that stop institutional investors from fully diversifying their portfolios, e.g., John C. Coffee, Jr., Liquidity Versus Control: The Institutional Investor as Corporate Monitor, 91 CoLUM. L. REv. 1277 (1991).

3. Like Roe, I here take those regulatory differences as given. Elsewhere Roe has discussed the political origins of financial regulation in more detail. See Mark J. Roe, A Political Theory of American Corporate Finance, 91 CoLUM. L. REV. 10 (1991). For a discussion of the political dynamic behind economic regulation in Japan, see J. MARK RAMSEYER \& FRANCES MCCALL ROSENBLUTH, JAPAN'S POLITICAL MARKETPLACE (1993). 
securities markets. Consequently, securities-based competitors do not pose the same threat in Japan that they pose in the United States.

Roe also contrasts the basic financial structures of Japanese and American firms. Most crucially, he notes that Japanese banks tend to buy stock in the firms to which they lend money. As a result, Japanese managers often find large blocks of stock in their firms owned by banks. These blocks, according to Roe, reduce the managers' discretion. The shareholding patterns shift monitoring from the boards of directors to the institutional shareholders (the banks), in other words, and with the monitoring goes significant control. All this, Roe claims, largely follows from the regulatory constraints in place: Japanese regulators allow banks to buy stock; American regulators do not. But for the regulatory restrictions, American banks too might have become organizations that buy stock in their debtors.

\section{BANK SHAREHOLDING}

In positing this historical might-have-been, Roe may be right. Absent regulatory limits, American banks might have become institutions that buy their borrowers' stock. If legal restrictions more drastically circumscribe bank investments in the United States than in Japan, one reason American banks do not buy their clients' stock is easy. They do not buy stock because regulators do not let them. The harder question - and the one Roe may not satisfactorily answer-is why Japanese banks do buy their clients' stock and whether American banks would if they could. More abstractly, the question is the following: Why might the equilibrium in an apparently unregulated market be one where banks buy stock in the firms to which they lend money? To answer this question, I first consider a variety of unsuccessful hypotheses and then turn to a hypothesis that differs from the one Roe and other scholars advance.

\section{A. Unsuccessful Reasons}

\section{Controlling the Borrower}

Perhaps Japanese banks buy their clients' stock in order to influence or control those clients. Although Roe suggests this possibility, ${ }^{4}$ he never identifies the reasons banks want to influence or control their debtors. Consider four possibilities. First, a bank may believe it can help a firm better compete in the product market. If the bank simply has better information about suppliers or buyers, however, it need not buy stock to induce a firm to use the information. Rather, the firm's managers will use the information gladly, whether or not the bank owns stock. The bank would need to buy stock to

4. See, e.g., Roe, supra note 1, at 1943-45. 
force the firm's managers to take its advice only if it wanted to replace them with its own staff. Although bankers know how to lend money, they seldom know how to run factories. If a firm's managers are so inept that bankers can run the firm more efficiently, rational bankers will not lend the firm money. Prudent bankers only lend to people who show they can compete effectively in the product market on their own. ${ }^{5}$

Second, a bank may want to induce firms to borrow inefficiently large amounts of money or to borrow at supra-market rates. ${ }^{6}$ Because a bank makes money on its loans, it may hope to use its control over stock holdings to induce the firm's managers to borrow more money. The bank would then bear a small share of any resulting losses to the firm and earn $100 \%$ of the profits on the debt. If so, such a strategy might seem to pay. ${ }^{7}$ In fact, it seldom would; it would pay only to the extent capital markets were not competitive and bank reputations did not matter. All else equal, firms will avoid banks that induce debtors to incur inefficient loans. All else equal, banks will respond by cultivating reputations for supplying only efficient amounts of debt and only at market interest rates.

Third, a bank may want to ensure that a firm's managers do not pay themselves supra-competitive wages. Nonetheless, it is not clear either why a bank would much care about CEO salaries, or why managers would borrow from such a bank. CEO salaries are rarely large enough to lower significantly the value of a bank's loan. And if managers want to pay themselves high sums, they will not want to borrow from a bank that would constrain their salaries. Conversely, if they want to bind themselves to low salaries, they can write long-term contracts and dispense with special banking relationships. Whatever the case, we should not observe banks restraining managerial salaries.

Last, a bank may simply want enough potential control over a firm that-should the firm's managers ever adopt bad strategies-it can force those managers to change course. ${ }^{8}$ This possibility works no better than the others. First, rational banks will recognize a cheaper and more effective way to protect themselves: either lend money short term and refuse to renew loans if managers adopt poor strategies or negotiate protective loan covenants. These

5. Of course, the bank has less incentive to provide this information if it does not own the firm. By buying stock it can alleviate the conflict of interest-but not by much. A $5 \%$ interest gives banks an incentive to spend $\$ 1$ to provide information only if it generates a $\$ 20$ return to the firm.

6. A point nicely argued in MASAHIKO AOKI, INFORMATION, INCENTIVES, AND BARGAINING IN THE JAPANESE ECONOMY 148 (1988).

7. For an intriguing, related argument based on sequential monopolies in the capital and product markets, see David E. Weinstein \& Yishay Yafeh, Japan's Corporate Groups: Collusive or Competitive? An Empirical Investigation of Keiretsu Behavior (Nov. 3, 1992) (unpublished manuscript, on file with author).

8. Roe, supra note 1, at 1954. On the possibility that this will cause American banks problems (such as equitable subordination) later, see J. Mark Ramseyer, Explicit Reasons for Implicit Contracts: The Legal Logic to the Japanese Main Bank System (Sept. 1992) (unpublished manuscript, on file with author). 
measures Japanese banks regularly take. ${ }^{9}$ Second, by becoming a $5 \%$ shareholder, a bank does not decrease the risks it faces-it increases them. Although holding a 5\% stake may make the bank the firm's largest shareholder, if the managers want to ignore its demands, they can do so at will. ${ }^{10}$ By buying a minority equity stake, a bank simply increases its exposure.

\section{Insulation from Takeovers}

Perhaps Japanese banks buy stock in their debtors to help insulate those debtors from hostile takeovers. Other observers have made this argument often, and Roe mentions it too, though he does not make it a major part of his story. ${ }^{11} \mathrm{He}$ does well to avoid it. Managers may want to protect their jobs, but banks want debtors well-run. An acquiror will usually find it profitable to buy a firm only when it can improve the firm's performance. ${ }^{12}$ If a firm is well-run already, an acquiror cannot raise the price of its stock, and without a way to raise its stock price, will lose money on the purchase. If a firm is poorly run, however, an acquiror may be able to increase its efficiency. If so, a bank will want the acquiror to buy it; after all, it gains a better run client in the process. ${ }^{13}$

If a bank competed for customers by promising to help them avoid hostile acquirors, it would invite classic problems of adverse selection. Because the firms that face the most severe threat of a hostile acquisition are the most inefficiently run firms, the firms with the worst managers would necessarily find the bank's protection most attractive. A bank that offered protection from takeovers would thus attract as clients the most badly run firms. The worse a

9. See J. Mark Ramseyer, Legal Rules in Repeated Deals: Banking in the Shadow of Defection in Japan, 20 J. LEGAL STUD. 91, 105 (1991).

10. Moreover, a debtor can ignore a shareholder bank even if the bank manages to organize Roe's coalition of 20 to $25 \%$ of the outstanding stock. See Roe, supra note 1, at 1939-41.

11. Roe, supra note 1 , at $1945,1964-65$.

12. See Roberta Romano, A Guide to Takeovers: Theory, Evidence, and Regulation, 9 YALE J. REG. 119 (1992).

13. Granted, equityholders do have an incentive, once debt is in place, to increase the risk level of the projects the firm undertakes (to the detriment of the creditor). See Romano, supra note 12, at 136-37. An acquiror could also make a takeover profitable through such a ploy-but only if it did not need to renew its bank loans. Because most Japanese bank loans are short term, see Ramseyer, supra note 9, at 105, this is generally not a real risk.

Some scholars have argued that the protection from takeovers is necessary in Japan to prevent investors from opportunistically reneging on long-term labor contracts. See, e.g., PAUL SHEARD, STABLE SHAREHOLDINGS, CORPORATE GOVERNANCE, AND THE JAPANESE FIRM (Institute of Social \& Economic Research, Osaka University Discussion Paper No. 281, Sept. 1992). It is not clear, however, why contractual remedies like golden parachutes would not solve this problem more cheaply, see Romano, supra note 12 , at $137-42$, or how the acquiror could do business in the future once it had earned a reputation for reneging on implicit labor contracts, see EASTERBROOK \& FISCHEL, supra note 2, at 182. 
firm is run, the worse credit risk it presents. And the worse credit risk its clients pose, the worse the bank itself performs. ${ }^{14}$

\section{Quality Certification}

Perhaps banks buy stock in their debtors because the purchase (somehow) signals that the banks are monitoring the firms on behalf of other investors. Through the purchase, in other words, perhaps banks certify the quality of the managers. Prominent scholars have written widely on this alleged role that Japanese main banks play as "delegated monitors," 15 and Roe accurately draws upon their work. ${ }^{16}$ The logic is much the same as that which $\mathrm{J}$. Bradford De Long claims governed the House of Morgan's role in turn-of-the-century American corporate finance. ${ }^{17}$ According to De Long, the House of Morgan cultivated a reputation for carefully monitoring the firms with which it became involved. As a result, if Morgan placed one of its men on a firm's board of directors, it raised the price of the firm's stock between $5 \%$ and $40 \%$. So too in Japan, explain recent scholars. Main banks monitor a firm on behalf of other investors and, in the process, increase the firm's value.

Unfortunately, no one has systematically shown that Japanese main banks play this role. Granted, scholars have collected anecdotes about Japanese banks intervening in troubled firms, but they could easily collect similar anecdotes in the United States. Creditors everywhere do some monitoring. The question is whether Japanese main banks do significantly more than other banks

14. On why the ability to adjust interest rates does not make banks indifferent to credit risk, see Joseph E. Stiglitz \& Andrew Weiss, Credit Rationing in Markets with Imperfect Information, 71 AM. ECON. REv. 393 (1981).

Two caveats are in order. First, adverse selection would not necessarily occur if the bank monitored the firm as aggressively as the takeover market would. The borrowers who would go to the bank would then simply be firms with managers who preferred to be monitored by the bank rather than by the takeover market. Yęt, three problems emerge in this context. (1) As noted below, no one has shown that banks do monitor on behalf of equityholders in Japan. (2) If the banks were to monitor on behalf of equityholders with the severity of the takeover market, it is not immediately obvious why managers would prefer such monitoring. Presumably, if an acquiror would fire a manager, so too in most cases would the bank. (3) Banks could monitor firms whether or not they owned $5 \%$ of the stock. Stock ownership and bank monitoring are conceptually distinct issues, since 5\% stock ownership does little to induce a bank to monitor at optimal levels.

Second, the bank might decide to accept modest amounts of adverse selection (a pool of more poorly run debtors) in exchange for side payments. The payments could be in the form of an agreement by the manufacturer to buy the bank's stock and help insulate it (the bank) from a takeover-though Ministry of Finance regulation probably works as a sufficient barrier to bank takeovers. Alternatively, the payment could be in the form of higher interest rates-though as noted below no evidence of such high rates exists.

15. Excellent introductions to this literature on Japan, much of which is in Japanese, appear in MASAHIKo AOKI, THE ECONOMIC ANALYSIS OF THE JAPANESE FIRM (1984) and SHEARD, supra note 13; see also Paul Sheard, The Main Bank System and Corporate Monitoring and Control in Japan, $11 \mathrm{~J}$. ECoN. BehaV. \& ORGANIZATION 399 (1989). More generally, see Douglas W. Diamond, Monitoring and Reputation: The Choice Between Bank Loans and Directly Placed Debt, 99 J. POL. ECON. 689 (1991).

16. Roe, supra note 1 , at 1944.

17. J. Bradford De Long, Did J.P. Morgan's Men Add Value? An Economist's Perspective on Financial Capitalism, in INSIDE THE BUSINESS ENTERPRISE: HISTORICAL PERSPECTIVES ON THE USE OF INFORMATION 205 (Peter Temin ed., 1991). 
elsewhere. This, no one has shown. Second, no one has shown how firms would compensate main banks for any certifying service they did perform. A main bank will not certify quality, however, without demanding pay for the service. Since it only owns $5 \%$ of a firm's stock, absent such compensation it would spend an extra $\$ 1.00$ to monitor only if the additional monitoring thereby increased the firm's value by $\$ 20.00$. Yet no one has found any evidence of compensation. As a possible source of compensation, for example, some scholars have asked whether Japanese main banks earn a higher interest rate on their loans than other banks. They find no such rates. Others suggest that firms purchase larger shares of the main banks' fee-based services. Because all firms need these services, though, this suggestion implies that all firms could receive the certification service by routing their service business appropriately. All firms of equal size have roughly equal demand for fee-based services and would thus receive roughly equal monitoring and certifying services. Unfortunately again, the point is belied by the enormous heterogeneity in the Japanese economy and the large number of firm failures. ${ }^{18}$ Ultimately, compensation is critical. Absent compensation, banks should do no more than look out for themselves. Absent compensation, the best guess about certification may be that it does not occur.

\section{Credible Commitments}

Perhaps Japanese banks buy stock in their debtors to promote long-term relations. Perhaps, in other words, bank shareholdings form part of a pattern of "credible commitments" in long-term relationships in Japan. ${ }^{19}$ Oliver Williamson is justly famous for his 1983 article on credible commitments, and legal scholars rightly incorporate his analysis into their scholarship when they can. ${ }^{20}$ Nonetheless, the analysis does not apply here, for not every reciprocal asset-holding arrangement makes commitments credible. An arrangement increases credibility only when the assets are worth more if the relationship continues than if it does not.

Robert Cooter and Thomas Ulen give the nicest example of Williamson's intuition. ${ }^{21}$ Picture, they suggest, two kings. They have fought each other for years, but now want a stable peace. They realize that they both love diamonds

18. On the absence of compensation, see generally Yoshiro Miwa, Mein banku to Nihon no shihon shijo [Main Banks and Japanese Capital Markets], KıN'YU, Aug. 1991, at 11; Akiyoshi Horiuchi \& Shin'ichi Fukuda, Nihon no' mein banku wa dono yona yakuwari a hatashita ka? [What Role Has the Japanese Main Bank Played?], 6-3 NICHIGIN KIN'YU KENKYU 1 (1987); Ramseyer, supra note 9, at 113-14. On the absence of monitoring, see generally YOSHIRO MIWA, KIN'YU GYOSEI KAIKAKU [FINANCIAL ADMINISTRATION REFORM] 188 (1993).

19. See Roe, supra note 1 , at 1988-89.

20. Oliver E. Williamson, Credible Commitments: Using Hostages to Support Exchange, 73 AM. ECON. REV. 519 (1983).

21. ROBERT COOTER \& THOMAS ULEN, LAW AND ECONOMICS 246 (1988). 
and adore their sons. In order to preserve peace, ask Cooter and Ulen, should they trade diamonds or should they trade their sons? Suppose they exchange diamonds. If one of them starts a war, each will find himself with the other's diamond. Each diamond is worth the same whether the countries are at war or at peace, and if either king does not like the shape or color of the other's diamond, he can sell it and buy another. Whatever else diamonds may buy, they will not buy peace.

Suppose that the kings exchange sons. If one of them starts a war, he will find that he has lost his own son and gained his nemesis' son. Although he adores his own son, he has traded him for a man whom he can at best use as a slave. Since spoiled princes make bad slaves, each king has sacrificed an asset of great value (a son) for one of little value (a surly slave). Rather than make such a sacrifice, each king will avoid war.

Consider now the Japanese shareholding arrangements. The firms involved have sold stock to their banks. The shares have a market price and no other value. In Cooter and Ulen's terms, the shares are diamonds, not sons. Should either the bank or the firm choose to end its relations with the other, the bank can sell its stock on the open market. Because the demand for any given company's stock is infinitely elastic, the bank should obtain the stock's full economic value. ${ }^{22}$ As a scheme to maintain a continued relationship, the shareholding arrangement simply does not work.

By anyone's standards, the recent models of monitoring, certifying, and credible commitments are sophisticated-often brilliant-models. Unfortunately, simple cynicism may be the best response to some of their applications. One Japanese economist friend of mine took that cynicism farther over lunch last year than anyone else I have met:

Bag the main bank stuff. The reason there're all these main bank papers doesn't have a thing to do with what Japanese banks do. They don't do anything special. Instead, this whole discussion is theory-driven. There're all these fancy signalling, monitoring, and principal-agent models out there in status economics journals, but until people thought up the Japanese banking story no one had any facts to apply them to. So my friends started dreaming up this main bank stuff. Now these stories about main bank monitoring give them a great set of anecdotes to apply their high-tech models to. They're relatively plausible, too, since they perpetuate lots of stereotypes about the Japanese economy that the older academics taught-you know, those professors who were into all that dreadfully dogmatic Germanic theory. That's all there is to it. Anyway, how come you order sashimi every time we have lunch?"

22. The only exception would occur if the bank's shareholding added value to the firm-presumably through monitoring. Yet, as mentioned in note 14 , supra, bank monitoring is conceptually independent of the bank's owning $5 \%$ of the firm's stock. 
"No match made in heaven," he might have added—quoting F.M. Scherer-"is more blissful than an extant economic theory that finds an important real-world phenomenon to explain."23

\section{B. Simpler Reasons}

If these sophisticated reasons do not fit Japanese facts, the reason Japanese banks buy their clients' stock may be simpler: they may buy the stock because they believe it is underpriced. Before making a loan, the bank has an incentive to gather information about the firm's creditworthiness, and in convincing the bank to make the loan, the firm has an incentive to give the bank extensive information about itself. In the process, the bank may learn information not yet incorporated into share prices. If so, the bank will buy the firm's stock for the same reason Ivan Boesky bought stock: to take advantage of a bargain.

Because a Japanese bank can legally buy stock, it will try to diversify its investments in the stock market. Since the market is relatively efficient, most stocks the bank could buy present the same expected risk-adjusted return. Other than concern over assembling a diversified portfolio, the bank will thus find one stock much the same as any other. Accordingly, the bank's decision to buy a client's stock usually imposes no extra costs. If the client's stock appears not to reflect some positive inside information, the bank now has an especially strong incentive to buy it. Eventually the information will be incorporated into the price of the stock, and in the meantime the bank will earn a capital gain. In this world, bank shareholding patterns are simply an example of (harmless) insider trading. ${ }^{24}$

The puzzle is why banks rarely seem to sell their borrowers' stock. The solution-admittedly tentative-may involve four related points. First, although a borrower has incentives to convey undisclosed positive information to the bank in order to obtain cheaper loans, it has little incentive to convey undisclosed negative information later. Consider a firm that is finishing work on a radically new product when it applies for a loan. Suppose, for example, that Toshiba discovers a new technology for a picture tube that is clearer and cheaper than the Trinitron. Lest it lose its lead-time monopoly, it may decide not to disclose the information to the public until it is ready to market the tubes. But if the higher anticipated profits might cause its bank to lend money

23. F.M. Scherer, Corporate Takeovers: The Efficiency Arguments, 2 J. ECON. PERSP. 69, 69 (1988).

24. On Japanese insider trading provisions, see, e.g., Aikio Tekeuchi, Insaidaa torihiki kisei no arikato [The Proper Regulation of Insider Trading], 964 JuRISUTO 42 (1990). Most observers consider these provisions largely ineffective. Roe, supra note I, at $1987 \mathrm{n.193}$, and I agree that one testable implication of this hypothesis is that banks will tend to buy a client's stock either when the banking relationship begins or when a loan comes up for renewal. We disagree about whether the data are consistent with that implication. Roe also raises the consistency of bank shareholding percentages across the top companies as an objection to this hypothesis. Id. That fact, however, is likely just an artifact of the limits on bank shareholding found in the Japanese antitrust statute-limits discussed id. at 1959-60 n.94. 
more cheaply, it may disclose the information to the bank immediately. Consider, by contrast, a firm that learns that its planned technology has failed. Suppose, for example, that Sony learns that Trinitron tubes have caused 20,000 serious birth defects by exposing millions of pregnant women to higher levels of radiation than it had anticipated. Even if Sony discovers the failure before professional stock analysts do, it has no reason to rush to tell its bank the news. In short, borrowers will often give banks information suggesting that their stock is underpriced; they will seldom give banks information suggesting that their stock is overpriced. Thus, even if banks would gladly sell stock on inside information, firms have no incentive to give them the information that would enable them to do so. If and when banks sell their borrowers' stock, they seldom act on inside tips. Rather, they sell stock only when they decide to liquidate part of their portfolio.

Second, contrary to initial impressions, ${ }^{25}$ a bank does not "leave money on the table" by continuing to hold stock after inside information becomes public. The bank will always want to invest some of its assets in stock. Once the stock price incorporates the inside information, all stocks will present the same ex ante returns-and the bank may as well keep its money invested in its borrowers' stock. Having bought that stock when it was relatively cheap, the bank loses nothing by continuing to hold it.

Third, bank monitoring is most intense at the outset of a commercial relationship. The bank expends the bulk of its monitoring effort in choosing a creditworthy client. It then drafts a loan contract on terms (security interest, third-party guarantee, and length of term) that minimize the firm's ability to exploit the bank opportunistically. ${ }^{26}$ Having expended this initial effort, the bank spends less of its resources monitoring the firm later and thus is less likely to learn of problems indicating that it should sell the stock.

Finally, perhaps we have our facts a bit wrong. Perhaps Japanese banks sell their borrowers' stock more often than we American academics assume. Journalists at least claim that the banks do sell the stock they buy in their clients, and Japanese academics are beginning to make the point as well. ${ }^{27}$ The entire puzzle, in short, may be vastly overblown.

25. See Roe, supra note 1 , at 1987 n.193.

26. See Ramseyer, supra note 9, at 101-02.

27. Quentin Hardy, Japan Stock Woes Hit Small Companies, AsIaN WALL ST. J., July 24-25, 1992, at 1; Michio Kunimura, Kabushiki mochiai no shorai [The Future of Cross-shareholdings], in 21-SEIKI No NIHON NO KIGYO KIN'YU [JAPANESE CORPORATE FINANCE IN THE 21ST CENTURY] 126, 139-40 (Sogyo kenkyu kaihatsu kiko ed., 1988); Takatoshi Ito \& Takeo Hoski, Kigyo guruupu kessokudo no bunseki [An Analysis of Industrial Group Cohesiveness], in GENDAI NIHON NO KIN'YU BUNSEKI [FINANCIAL ANALYSIS OF MODERN JAPAN] 73 80-86 (Akiyoshi Horiuchi \& Naoyuki Yoshino eds., 1992). 


\section{WHY CORPORATE GOVERNANCE}

Consider a final question: Why are American corporate law scholars so curious about stock ownership by Japanese banks? So Japanese banks buy stock in their borrowers. Why does anyone care? On a superficial level, the answer lies in the way Roe thoughtfully ties the question to the current debate over "corporate governance." On a deeper level, that answer leads to the question of why recent scholars find corporate governance so fascinating.

\section{A. The American Problem}

\section{Manne}

It all began not long ago-for it mostly began with Henry Manne's 1965 article on the corporate control market. ${ }^{28}$ Manne asked why most corporate managers maximized profits even when no one seemed to force them to do so. The answer, he suggested, had nothing to do with law. Instead, it lay in a market few had yet noticed: the market for corporate control. If managers stopped maximizing profits, stock prices would fall. In turn, those lower prices would provide an incentive for ambitious entrepreneurs to buy control of the firm. They would do so because they could then fire the managers, turn the firm around, boost stock prices, and pocket the gain. Precisely because entrepreneurs could take these actions, they would seldom have the chance. Precisely because managers knew entrepreneurs could make money by sacking them if they did anything else, they maximized stock prices.

For scholars who cared about social scientific theory, the corporate control market was a godsend. With it, they now had a full complement of markets that constrained the various participants in the corporate enterprise. Firms may be collections of people contracting with each other to provide assorted services, but they contract in a world where markets constrain their ability to act opportunistically. ${ }^{29}$ Employees compete in a labor market, investors compete in a capital market, and the firm itself competes in a product market. Post-Manne, managers managed within the competitive constraints of a corporate control market.

Each of these markets helped prevent participants in the firm from exploiting each other. In the process, each market also reduced the need for the legal system to provide mandatory terms. Together, therefore, these markets made much of labor law, securities law, and products liability law possibly

28. Henry G. Manne, Mergers and the Market for Corporate Control, 73 J. POL. ECoN. 110 (1965). Or maybe it began with Robin Marris, A Model of the "Managerial" Enterprise, 77 Q.J. ECON. 185, 189 (1963).

29. See Michael C. Jensen \& William H. Meckling, Theory of the Firm: Managerial Behavior, Agency Costs and Ownership Structure, 3 J. FIN. ECON. 305 (1976). 
redundant and probably inefficient. If, as Manne argued, the capital market doubled as a corporate control market, a market also constrained managers from exploiting shareholders. Like the other fields, corporate law now could and should abandon mandatory terms.

\section{CTS}

It all made perfect sense. And by 1990 it no longer seemed to work. Either my watch has stopped or the hostile takeover boom just died, as Marx, upon taking the pulse of matters, once remarked. After $C T S,{ }^{30}$ state legislators found that they could stop the takeover of firms incorporated in their respective states without violating the Constitution. Because managers decided where the firm incorporated, managers could now protect their jobs by incorporating in states with antitakeover statutes, and states could now boost tax revenues by providing them a haven.

This was not supposed to happen. States were not supposed to be able to make money by offering inefficient corporate statutes. William Cary had predicted that they would, ${ }^{31}$ but modern scholars had proven Cary wrong. Ralph Winter best explained why. ${ }^{32}$ Suppose the corporate law of state $A$ made it easier for managers to exploit shareholders. The stock of firms incorporated in $A$ should trade at a lower price than the stock of firms incorporated elsewhere. If so, entrepreneurs should be able to buy firms incorporated in $A$, reincorporate them elsewhere, and resell them at a profit. Thus, if state $A$ offered an inefficient corporate statute, the corporate control market itself would ensure that few firms incorporated there.

Now suppose that an inefficient corporate law provision, prompted by CTS, crippled the corporate control market. Because Winter's story partly depended on entrepreneurs taking over firms incorporated in states with inefficient corporate law statutes and making money by reincorporating them elsewhere, if a state statute prevented them from launching a takeover bid, incumbent managers could safely incorporate in the inefficient state. CTS seemed to destroy a major part of Winter's argument, and scholars could pretend they were back in Cary's race to the bottom.

Furthermore, note that for purposes of ensuring legal efficiency, a continuing potential for mergers would not necessarily do. In his 1965 article, Manne had argued that a "market for mergers" constrained management. ${ }^{33}$ In

30. CTS Corp. v. Dynamics Corp. of America, 481 U.S. 69 (1987).

31. William L. Cary, Federalism and Corporate Law: Reflections Upon Delaware, 83 YALE L.J. 663 (1974).

32. Ralph K. Winter, Jr., State Law, Shareholder Protection, and the Theory of the Corporation, $6 \mathrm{~J}$. LEGAL STUD. 251 (1977). Note that Winter did not rely solely on the takeover market, but also on the capital market generally-on the less than intuitively obvious notion that firms that incorporated in exploitation-possible states would face a higher cost of capital than firms that incorporated elsewhere.

33. Manne, supra note 28 , at 117-19. 
fact, it may do no such thing. Mergers proceed only with a vote of the existing board. If, for example, T. Boone Pickens wants to merge a badly run firm, he must first clear the deal with the incumbent board. In the process, the firm's managers can sometimes (not always) obtain payoffs that compensate them for their lost perquisites. This is a breach of fiduciary duty, to be sure, but a breach that a good corporate lawyer can often disguise. In short, a corporate control market disciplines managers only if bad managers lose their jobs without compensation. Because managers can usually veto mergers, they can sometimes demand compensation equal to their forgone future perquisites. In the process, the market may lose its bite.

\section{Corporate Governance}

Much of the passion behind the recent "corporate governance" debate arises from the renewed potential for mandatory corporate law provisions in the post-CTS, post-takeover world. After Manne, scholars found it hard to promote mandatory terms, for they had traditionally justified their efforts by the need to prevent exploitation. In this brave new Mannean world, the potential for takeovers seemed to make their proposals both unnecessary and unwise. Most of what they had earlier said about the law simply seemed wrong. CTS promised to undo this revolution. ${ }^{34}$ In the post-CTS world, exploitive strategies seemed not only possible, but potentially profitable. The corporate control market no longer seemed to constrain managers, and interventionist scholars could again indulge their whimsy for mandatory terms.

In the end, much of the fascination with "corporate governance" reflects this academic taste for mandatory terms. ${ }^{35}$ Now that the corporate control market no longer seems to constrain exploitation, many scholars ${ }^{36}$ seem suddenly to have more to offer the world-to be able to remake the world in their own image of mandatory corporate terms. Deceptively to be sure, the corporate governance debate promises a return to this pre-Mannean world.

34. See generally Jonathan R. Macey \& Geoffrey P. Miller, Toward an Interest-Group Theory of Delaware Corporate Law, 65 TEx. L. REv. 469, 512-22 (1987) (effect of poison pills on Cary-Winter debate). Mark J. Roe, Takeover Politics, in THE DEAL DECADE: What TAKEOVERS AND LEveraged BUYOUTS MEAN FOR CORPORATE GOVERNANCE 321 (Margaret M. Blair ed., 1993) (effect of antitakeover statutes on Cary-Winter debate). It is unclear how badly the opinion did cripple the takeover market. Firms can and often do opt out of state antitakeover provisions, some states have no antitakeover statutes at all, and even firms in states without such provisions can stop takeovers through poison pills.

35. See, e.g., Symposium, Contractual Freedom in Corporate Law, 89 CoLUM. L. REv. 1395 (1989)

36. Excluding Roe-Roe studies Japan and (rightly) urges American courts and legislatures to offer a more permissive corporate law regime than available now. Roe, supra note 1, at 1990. 


\section{B. The Japanese Example}

In their zeal for mandatory terms, modern scholars read the wrong clues from Japan. It simply does not follow from the Japanese experience that judges in takeover-free worlds should invent such terms. On the contrary, if Japan presents any message at all, it is that such terms are unnecessary. Even absent takeovers, firms largely solve their corporate governance problems on their own, safely beyond the reach of law professors.

\section{The Marginal Effect of Takeovers}

In the 1980's, acquirors in the United States launched forty or fifty tender offers a year. In each bid, they paid target shareholders $20 \%$ to $30 \%$ more than the market price $^{37}$ and roughly broke even. On average, therefore, they improved corporate efficiency by twenty to thirty percent in forty-odd cases a year. The issue is whether they accomplished anything else.

During the 1980's, some corporate law scholars argued that takeovers accomplished much more. To these theoretically inclined scholars, most of the benefit of takeover bids accrued to shareholders in the firms no one sought to acquire. These shareholders benefited from the threat of a bid. Precisely because managers feared that an acquiror would bid for their firm if they did not manage it well, they managed it well.

If these corporate law scholars were wrong, CTS-as bad a decision as it was-may not be quite the tragedy that it seems. And whether or not the scholars were wrong depends on how effectively other markets discipline managers. Even if managers managed a firm well, they need not have been acting solely out of fear of a takeover. They may have feared the effects of other markets as well. Most obviously, if they did not manage the firm well, the firm might not have been able to pay its bills. Ultimately, employees (including the managers) would have lost their jobs. As in much of law, the question concerns marginal effects. ${ }^{38}$

\section{2. "Lessons" from Japan}

On the marginal effect of takeovers, Japan does provide one data point. During most of the 1980's, most Japanese managers ran their firms reasonably well. They did so free of both takeovers and the mandatory terms that the corporate governance crowd now advocates. Take each of these points in a bit

37. Gregg A. Jarrell et al., The Market for Corporate Control: The Empirical Evidence Since I980, 2 J. ECON. PERSP. 49, $51-53$ (1988).

38. Studies of the effect on stock prices of the adoption of poison pills show an immediate drop of $0 \%$ to $3 \%$. State antitakeover laws had a similar effect. See EASTERBrooK \& FISCHEL, supra note 2, at 196-97. 
more detail. First, most Japanese managers did their jobs successfully. Although this is a hard claim to prove, in a 1993 Yale symposium on "international competitiveness" it may also be unnecessary to prove. The surprise, however, is that Japanese firms maintained this "competitiveness" with the same attention to "short-term" stock prices that the scholars-turned-Washingtonian-bureaucrats now blame for the supposed lack of American competitiveness. According to economist Steven Kaplan, for example, Japanese firms tie executive salaries tightly to stock price. "If anything," he writes, "the compensation relation in Japan is more sensitive to stock performance" than in the United States. The incentives are not just a matter of money. If the stock price dips very far, Japanese firms simply fire their senior executives. ${ }^{39}$

Second, for several institutional reasons, Japanese firms in the 1980's faced almost no threat of a hostile takeover. To the extent firms used tender offers, they used them to finesse negotiated (friendly) business combinations, rather than hostile takeovers. ${ }^{40}$

Third, Japanese firms did not operate in the world that the recent corporate governance partisans would create. Proxy rules, for example, did not require firms to underwrite insurgent communications liberally. Financial intermediaries did not face drastic restrictions on diversification. Directors were not outside appointees. Banks did not monitor their debtors much more closely than they do here. The regulatory restrictions that the firms faced were not academically inspired proposals to improve corporate performance, but merely politically driven pork-barrel schemes. ${ }^{41}$

By all odds, most Japanese managers managed their firms well simply as a result of the multiple market and organizational incentives they faced. To do business, their firm had to compete in the labor market, the capital market, and-most crucially-the market for the firm's products or services. ${ }^{42}$ If the firm could not compete, it went out of business. Within the firm, managers competed in elaborate organizational hierarchies. Senior managers competed by policing their subordinates. Junior managers competed by notifying their seniors of inefficient colleagues (or even superiors).

These incentives are not peculiar to Japan-exactly the same incentives exist in American firms. Ultimately, the same reasons explain why most firms

39. Steven N. Kaplan, Internal Corporate Governance in Japan and the U.S.: Differences in Activity and Horizons (Jan. 1992) (unpublished manuscript, on file with author). This itself, of course, is beneficial corporate goverance-as Roe rightly points out. Letter from Mark Roe to author (Apr. 14, 1993) (on file with author).

40. See generally J. Mark Ramseyer, Takeovers in Japan: Opportunism, Ideology and Corporate Control, 35 UCLA L. REv. 1 (1987).

41. See generally RAMSEYER \& ROSENBLUTH, supra note 3.

42. The pressures are particularly compelling for the firms about which Americans know the most-the firms that export to the West. These firms face not only domestic competitors but international competitors. Often, they face tariffs in countries where they would sell besides. American anecdotal comparisons generally compare two disparate groups: all American firms with only those Japanese firms that export. 
in both countries are efficient, but say nothing about why firms might be more efficient in one country than in the other. Yet no one has shown that they are. Most Japanese firms are well-run; most American firms are well-run. Notwithstanding recent IBM suicide schemes and the recent fascination with "international competitiveness," no one has shown that American firms are particularly "uncompetitive." Elementary notions of comparative advantage suggest that some firms in any country will always be uncompetitive compared to firms in the same industry elsewhere. No one-not in Washington and not in any university-has shown that anything more is at stake. "Competitiveness" is a nonissue.

\section{CONCLUSION}

Roe provides a sophisticated, wonderfully nuanced picture of Japanese banks. He shows how and when they buy stock in their clients. He notes that American banks do not buy such stock and rightly explains that the law bars them from doing so. Why Japanese banks do buy their clients' stock, and whether any of this justifies legal changes here, are harder questions.

Several complicated explanations for Japanese bank shareholding do not work, and the explanation that may work best is simple. Banks are not buying stock to control their clients, for they would not lend to a client that would do better under banker management. They are trying to protect their clients from takeovers, for they have no interest in keeping their clients badly managed. They are not holding shares to certify the quality of the firm, for they earn no compensation for doing so. They are not trying to protect long-term relationships, for shareholdings do not have value that is specific to the relationship at issue. They buy their clients' stock simply because they find, in the course of investigating their clients' creditworthiness, undisclosed inside information. They buy stock simply because they find it underpriced.

As Roe rightly demonstrates, there are no lessons from the Japanese experience. Neither Japanese nor American firms are particularly badly managed. This may be a symposium on "international competitiveness," but ultimately nothing is the matter with American competitiveness. Like most Japanese firms, most American firms are well-managed. The reason is straightforward: most badly managed firms (indeed virtually all badly managed firms except the very large) either fire their managers and improve their performance, or go out of business. Here or there, a wide variety of markets (wholly aside from the corporate control market) constrains managers. Here or there, nothing warrants renewed attempts by law professors to dictate the shape of the corporate bargain that managers and investors make. Here or there, managers and investors do just nicely on their own. 